\title{
Influence of Groundwater Hypothetical Salts on Electrical Conductivity Total Dissolved Solids
}

\author{
S. A. M. Al Dahaan', Nadhir Al-Ansari' ${ }^{2}$, Sven Knutsson ${ }^{2}$ \\ ${ }^{1}$ Department of Geology, Faculty of Science, University of Kufa, Kufa, Iraq \\ ${ }^{2}$ Lulea University of Technology, Lulea, Sweden \\ Email: nadhir.alansari@ltu.se
}

How to cite this paper: Al Dahaan, S.A.M., Al-Ansari, N. and Knutsson, S. (2016) Influence of Groundwater Hypothetical Salts on Electrical Conductivity Total Dissolved Solids. Engineering, 8, 823-830. http://dx.doi.org/10.4236/eng.2016.811074

Received: October 10, 2016

Accepted: November 26, 2016

Published: November 29, 2016

Copyright $\odot 2016$ by authors and Scientific Research Publishing Inc. This work is licensed under the Creative Commons Attribution International License (CC BY 4.0).

http://creativecommons.org/licenses/by/4.0/

\begin{abstract}
A relationship between electrical conductivity (EC) and total dissolved solids (TDS) was tested for solutions of same salinity levels with respect to different artificial salts with their combinations. Results showed remarkable jumping at the order of the artificial salt sequence specially that of the magnesium type. A computer model is designed with an input of EC and TDS. The output will be the possible prevailing artificial salts. The accuracy of the model was tested by using the groundwater data of Safwan-Zubair area south of Iraq and it proved to be significant at $95 \%$ matching. The $5 \%$ unmatched results are due to the possibility of having more than one type of prevailing salt.
\end{abstract}

\section{Keywords}

Electrical Conductivity, A Computer Model, Artificial Salts, Groundwater, Total Dissolved Solids

\section{Introduction}

Salinity is a measure of the amount of salts in the water, while total dissolved solids (TDS) as salinity parameters are often calculated using laboratories test [1]. When salts are dissolved in water, their ions dissociated and increased both the amounts of dissolved solids in the solution and their conductivity [2]. Electrical conductivity gives an indication of the amount of total dissolved substitution in water [3]. The estimations of total dissolved solids (TDS) content are based on electrical conductivity (EC) measurements [4].

Electrical conductivity (EC) for groundwater is the ability of $1 \mathrm{~cm}^{3}$ water to conduct an electric current at $25^{\circ} \mathrm{C}$ and is measured in micro Siemens per centimeter, so it depends on the total amount of soluble salts (TDS) as charged particles [5] [6] [7] [8]. 


$$
\operatorname{TDS}(\mathrm{ppm})=0.64 \times \mathrm{EC}(\mu \mathrm{S} / \mathrm{cm})=640 \times \mathrm{EC}(\mathrm{dS} / \mathrm{m})
$$

Groundwater conductance is a function of type of present ions, types of dissolved constituents and temperature [9]. Electrical conductivity is an indirect measurement of salinity, and it is temperature dependent and good indicator of the total salinity, but it does not provide any information about the ionic composition within the water sample [10] [11]. The response of the conductance value to temperature changes is somewhat varies for different salts and many concentrations. In dilute solutions however, for most ions, an increase of $1^{\circ} \mathrm{C}$ can increase conductance by about $2 \%-3 \%$ [12]. It also increases with the increase of the total dissolved salts [13]. The variation of conductivity gives important information on the evolution of water quality. Electrical conductivity is a measurement to estimate the amount of total dissolved solids by factor of $0.55-0.90$ for converting conductivity into total dissolved solids [14]. The spatial distribution of EC is controlled by several factors and practices, which may cause salinity variation [8] [15] [16]. Some of these factors are the depth of the collected samples, concentration and type of concentration, mobility of groundwater, valence, temperature of water, type of soil or rock leaching, the long term flow with high rates of discharge, and the distance between the recharge and discharge area [13]. The internationally accepted standard unit for reporting EC of water is deciSiemens per meter $(\mathrm{dS} / \mathrm{m})$. Note that this standard unit was adopted recently. An older, equivalent unit often appears in water quality reports from the 1980s or earlier which is: milliohms per centimeter. Although the term "mhos" may at first appear strange, it was chosen by early researchers for reasons that involve physics. EC, as its name implies, is a type of conductivity-the opposite of resistivity, measured in ohms. Hence, for EC, researchers adopted the term "mho"-"ohm" written backwards. Here is a quick summary of the various EC units you might encounter when reading papers from the literature:

$$
1 \mathrm{dS} / \mathrm{m}=1 \mathrm{mmho} / \mathrm{cm}=1000 \mu \mathrm{mho} / \mathrm{cm} \text {. }
$$

Units used for measuring electrical conductivity of water are MicroSiemens per centimeter $\mu \mathrm{S} / \mathrm{cm}$, millisiemens per centimeter $(\mathrm{mS} / \mathrm{cm})$ and DeciSiemens per meter $\mathrm{dS} / \mathrm{m}$. Groundwater contains different of both ionic and uncharged species in various amounts and proportions that constitute the dissolved solids. Thus it is not clear whether specific conductance measurements can be used to obtain accurate estimates of TDS. The electrical conductivity for absolute pure water is $0.055 \mu \mathrm{S} / \mathrm{cm}$, distilled water $0.5 \mu \mathrm{S} / \mathrm{cm}$, power plant boiler water $1.0 \mu \mathrm{S} / \mathrm{cm}$, deionizer water $0.1-10 \mu \mathrm{S} / \mathrm{cm}$, good city water $50 \mu \mathrm{S} / \mathrm{cm}$, drinking water $0.5-1 \mathrm{mS} / \mathrm{cm}$, ocean water $53 \mathrm{mS} / \mathrm{cm}, 10 \% \mathrm{NaOH}$ $355 \mathrm{mS} / \mathrm{cm}$ and $10 \% \mathrm{H}_{2} \mathrm{SO}_{4}$ is $432 \mathrm{mS} / \mathrm{cm} \mathrm{[17].}$

Total dissolved solids term TDS describes all solids, commonly mineral salts that are dissolved in water [18] [19]. There is a close relation between TDS and the electrical conductivity [20]. As more salts are dissolved in water; the value of electric conductivity becomes higher. The majority of solids, which remain in the water after filteration are dissolved ions. Water of excellent purity without salts has a very low electrical conductivity (lennetech.com). Total dissolved solids TDS are differentiated from total suspended solids TSS, because the latter cannot pass through a filter of two micrometers 
and yet are called suspended in solution [21]. However, when the concentration of salt reaches a certain level, electrical conductivity is no longer directly related to salts concentration because of ion pairs weaken each other's charge, so that above this level, higher TDS cannot result equally higher electrical conductivity. Electrical conductivity can be converted to estimate total dissolved solids by using the following equation [13]:

$$
\mathrm{TDS}(\mathrm{ppm})=0.64 \times \mathrm{EC}(\mu \mathrm{S} / \mathrm{cm})=6.4 \times \mathrm{EC} \mathrm{mS} / \mathrm{cm}=640 \times \mathrm{EC}(\mathrm{dS} / \mathrm{m}) .
$$

Electrical conductivity for water is directly related to the concentration of dissolved ionized solids in water. Ions from the dissolved solids in water are creating the ability of water to conduct an electrical current. It can be measured by using a conventional conductivity meter or TDS meter within about $10 \%$ accuracy, when correlated with laboratory TDS measurements.

Relationship of total dissolved solids and specific conductance for groundwater can be approximated by the following equation (epa.gov):

$$
\text { TDS }=\text { keEC }
$$

where TDS is expressed in $\mathrm{mg} / \mathrm{L}$ or ppm and EC is the electrical conductivity in microSiemens per centimeter or $\mu \mathrm{S} / \mathrm{cm}$ at $25^{\circ} \mathrm{C}$. Correlation factor ke is between $0.55-0.8$.

Rainwater has TDS about of $20 \mathrm{ppm}$ or less. Fresh water of lakes, rivers, and groundwater is more variable, with TDS ranging from $20-1000 \mathrm{ppm}$. Brackish water is, by definition, water with TDS exceeding $1000 \mathrm{ppm}$ and ranging as high as that of seawater, at about 35,000 ppm.

Total dissolved solids TDS is the total amount of solids remaining when a water sample evaporates to dryness [22]. Dissolved solids are those that pass through a filter with $2.0 \mu \mathrm{m}$ or smaller pores. A simple method for determining the concentration of dissolved solids is to filter the water, evaporate the filtrate and weight the residue. The TDS represents a total summation of ionic concentrations of cations and anions. It is measured by the ppm or $\mathrm{mg} / \mathrm{l}$ units [9].

The aim of study is to present a model clarifying the effect of the prime salt at same salinity level on the values of the electrical conductivity. Also the effects of the presence of difference artificial salts at same salinity level on the electrical conductivity. Finally this model is programmed with input of electrical conductivity and total dissolved solids to predict the type of the artificial salt.

\section{Materials and Methods}

Preparation of different artificial salts at same level of salinity in five replicates was carried out. Salinity levels were taken from $500 \mathrm{ppm}$ with $500 \mathrm{ppm}$ increment up to 3000 $\mathrm{ppm}$. Then the salinity levels were increased by $1000 \mathrm{ppm}$ from $3000 \mathrm{ppm}$ up to 7000 $\mathrm{ppm}$. The electrical conductivity was measured by conductor meter at $25^{\circ} \mathrm{C}$ for prime salts and their combinations [23].

The statistical test $(\mathrm{F}, \mathrm{t})$ is applied for the predicted of TDS and the input TDS [24].

\section{Results and Discussions}

The obtained results for prime salt of chloride type started from top $\mathrm{NaCl}$ to $\mathrm{KCl}$ to 
bottom $\mathrm{CaCl}_{2}$ (Figure 1). At same TDS salinity Level, the EC values increase from bottom to top of the sequence. This means that for the same EC value the TDS increase from top to bottom. All of the prime salts were below the mixed water type number 4 . The $\mathrm{MgCl}_{2}$ jumped out of the sequence. The $\mathrm{MgCl}_{2}$ artificial prime salt jump from the chloride natural sequence to the sulphate sequence (Figure 2). The position is at the end of the sulphate replacing the $\mathrm{MgSO}_{4}$ position which is the second jump type. Here the value of the TDS at same level of EC will be from top to bottom increase. The sulphate sequence is of higher TDS than the chloride sequence at given level of EC. The

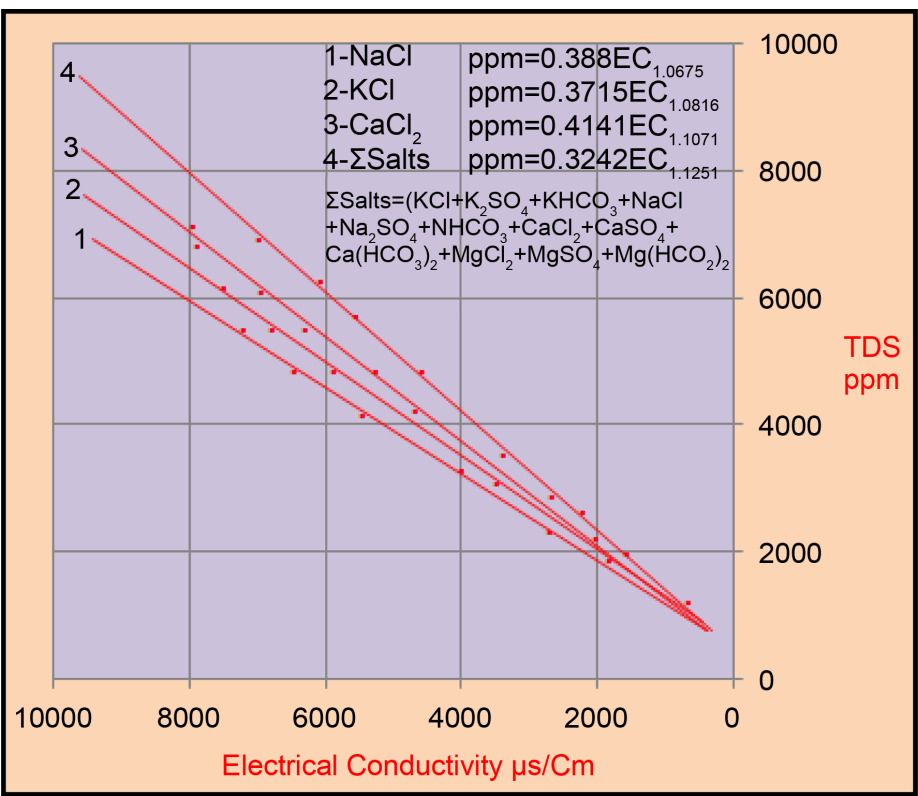

Figure 1. EC and TDS for prime salts 1,2, 3 and first stage mixed salts 4 .

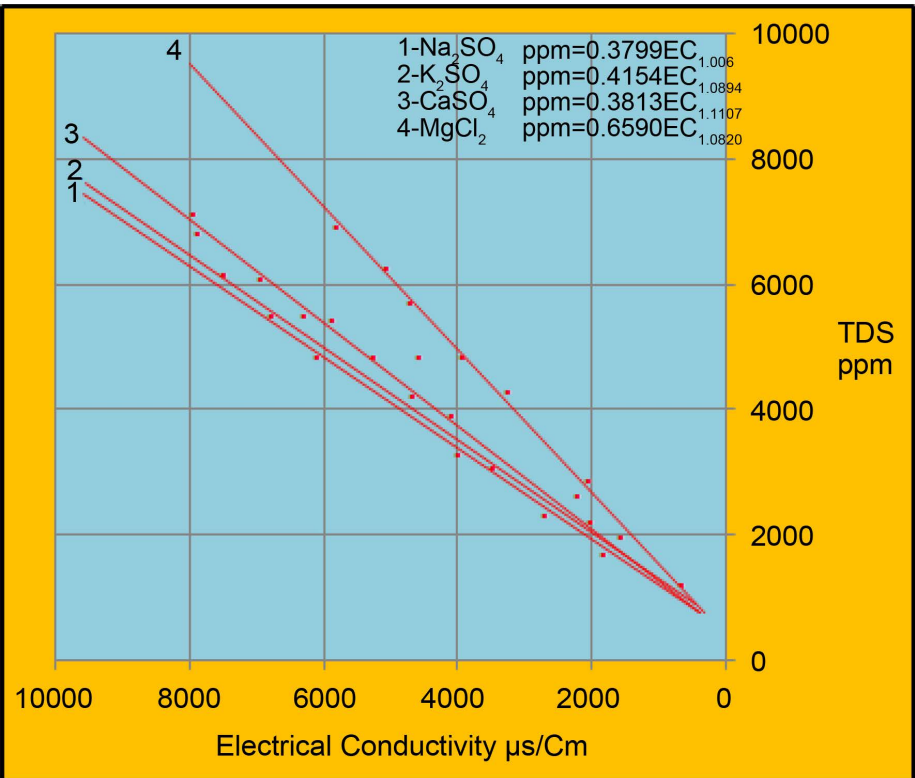

Figure 2. Prime salts EC and TDS second stage. 
bicarbonate sequence (Figure 3) is characterizes by the $\mathrm{KHCO}_{3}$ top passes toward $\mathrm{Ca}\left(\mathrm{HCO}_{3}\right)_{2}$ and then jumping to $\mathrm{NaHCO}_{3}$ and followed to the $\mathrm{Ca}\left(\mathrm{HCO}_{3}\right)_{2}$. The $\mathrm{MgSO}_{4}$ jumped from the sulphate to the bicarbonate sequence following the $\mathrm{NaHCO}_{3}$ and replacing the $\mathrm{Mg}\left(\mathrm{HCO}_{3}\right)_{2}$. The bottom of the sequence is $\mathrm{Mg}\left(\mathrm{HCO}_{3}\right)_{2}$.

The flow chart of such jump in the sequence of salts is shown in Figure 4. Also all the artificial salts of the chloride type $\mathrm{Na}, \mathrm{K}, \mathrm{Ca}$ and $\mathrm{Mg}$ were mixed with the sulphate and bicarbonate artificial salts combination. The obtained results showed that the EC value is decreased from the mixing of $\mathrm{Na}_{2} \mathrm{SO}_{4}$ to $\mathrm{K}_{2} \mathrm{SO}_{4}$ passed to $\mathrm{NaHCO}_{3}, \mathrm{KHCO}_{3}$ and

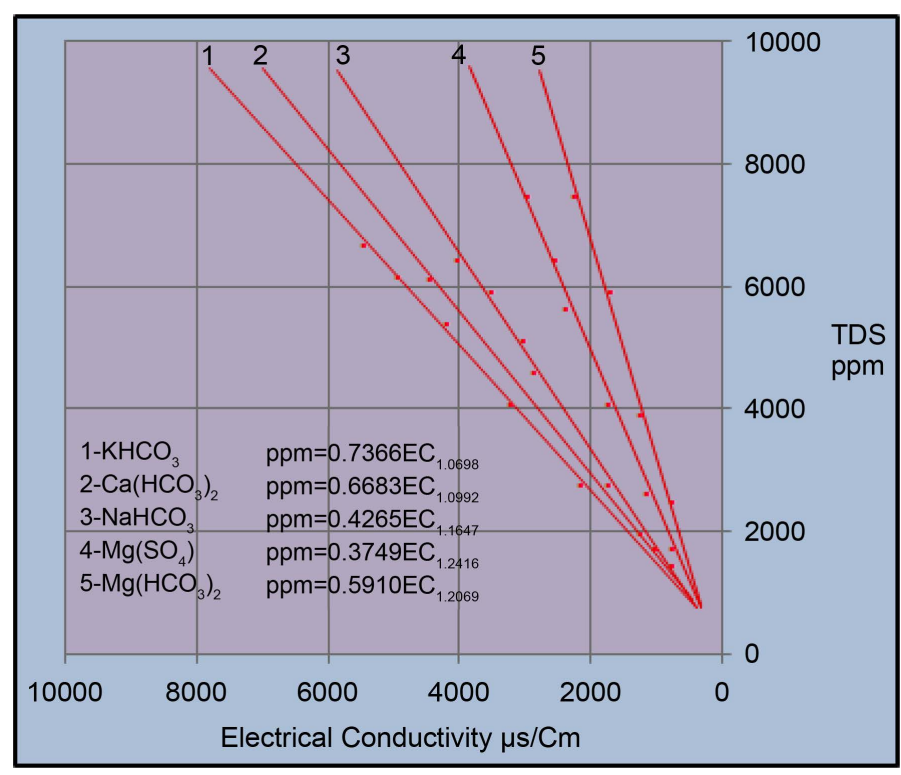

Figure 3. Prime salts EC and TDS last stage.

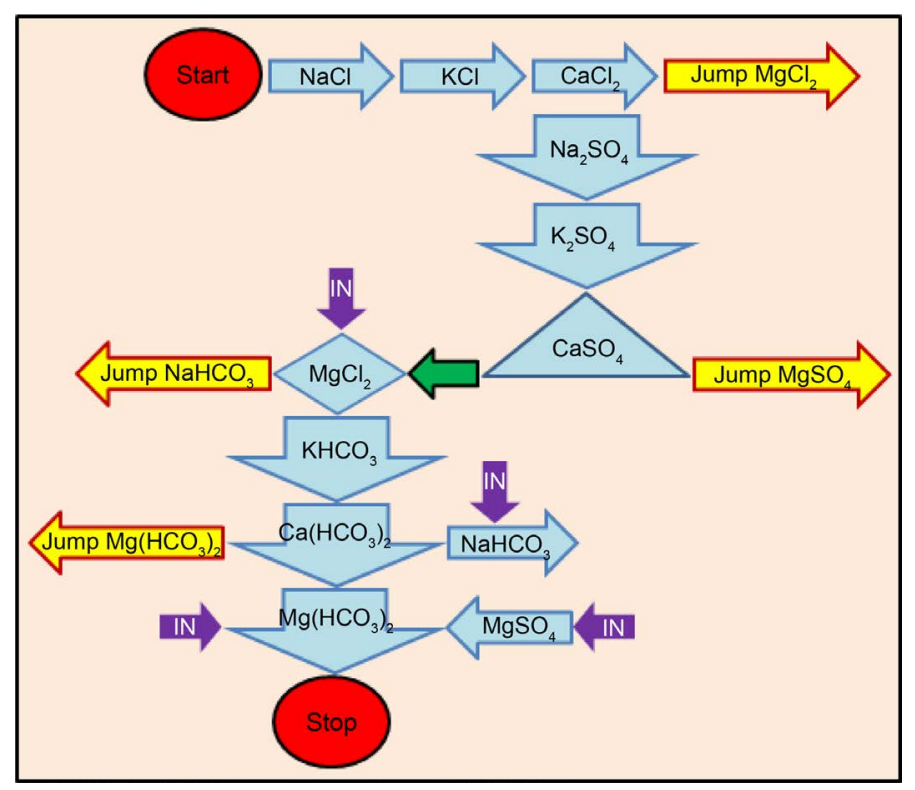

Figure 4. Flow chart for the jump of EC at same salinity TDS with different water type. 
ending by $\mathrm{MgSO}_{4}$. This is the same result of the obtained individual sequence. The TDS will increase from top to the bottom and all of the sequence is higher in TDS values than the sulphate at same level of EC. There is an overlap between the $\mathrm{KHCO}_{3}$ and the $\mathrm{MgCl}_{2}$ in position (Figure 5).

\section{Computer Model}

The mixed salt relationship presented in Figures 1-5, and type curve number 4 is the first point considered in the model. The calculated ECC by this type curve will be compared with the actual EC. There will be three conditions:

1) ECC < EC:

This is the condition of chorded artificial salt combination. Then Chloride Water Type will be in action.

2) ECC > EC:

This is the condition of sulphate and bicarbonate artificial salts. The $\mathrm{SOCH}$ subroutine will be in action.

3) $\mathrm{ECC}=\mathrm{EC}$ :

This is the ideal case of more than one prevailing artificial salt combination. The limits are taken for $\pm 5 \%$ relative difference. This mean matching of $95 \%$.

\section{Conclusion}

The prime salt of chloride group is of higher EC value than the sulphate water group followed by the bicarbonate of same salinity. This sequence is changed when salt combinations are considered. For chloride and sulphate groups, the EC value decreases from sodium to potassium and to calcium in a solution of same salinity. This order is

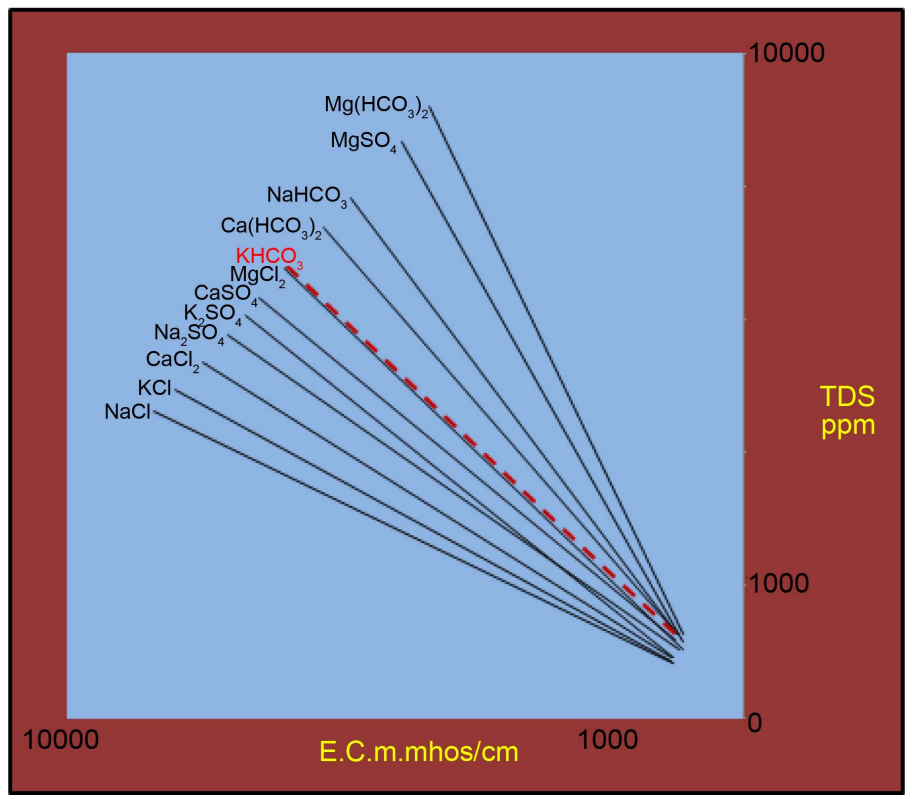

Figure 5. Prime artificial salts behavior with EC and TDS relationship. 
changed for bicarbonate group as the sodium bicarbonate salt is at the end of the sequence. The presence of the magnesium anion salts decreases the EC rapidly. The $\mathrm{MgCl}_{2}$ follows the $\mathrm{CaSO}_{4}$ and the $\mathrm{MgSO}_{4}$ follows the $\mathrm{NaHCO}_{3}$ and this sequence is ended by the $\mathrm{Mg}\left(\mathrm{HCO}_{3}\right)_{2}$. For the case that the magnesium is the prevailing cation, then the EC value is less than expected. There are significant differences in the EC values of the prime salts in a solution of same salinity in the mixed state. This fact is due to the behavior of the prime salts in a solution related to their stages of development and interaction. The mixed stat position is between chloride and the sulphate water groups, while the bicarbonate is still far away from the mixed condition. Thus it is not possible to use any relation of a given basin to another basin without taking into consideration the prevailing water type and salinity level. A computer model is built for the prediction of the type of the hypothetical salt. The input data are the EC and TDS. The calculated electrical conductivity ECC is according to the mixed condition of no prevailing salt. The relation between the actual and the calculated electrical conductivity will determine the type of prevailing salt.

\section{References}

[1] Siosemarde, M., Kafa, F., Pazira, E., Sedghi, H. and Ghaderi, S.J. (2010) Determine of Constant Coefficients to Relate Total Dissolved Solids to Electrical Conductivity. International Journal of Environmental, Chemical, Ecological and Geophysical Engineering, 4, 457-459.

[2] Hölting, B. and Coldewey, W.G. (2012) Hydrogeologie-Einführung in die Allgemeine und Angewandte. Springer Spektrum, Berlin, 439 p.

[3] Yilmaz, E. and Koc, C. (2014) Physically and Chemically Evaluation for the Water Quality Criteria in a Farm on Akcay. Journal of Water Resource and Protection, 6, 63-67. https://doi.org/10.4236/jwarp.2014.62010

[4] Hubert, E. and Wolkersdorfer, C. (2015) Establishing a Conversion Factor between Electrical Conductivity and Total Dissolved Solids in South Africa Mine Waters. Water SA, 41, 490-500. https://doi.org/10.4314/wsa.v41i4.08

[5] Todd, D.K. (1990) Groundwater Hydrology. John Wiley and Sons, New York, 535 p.

[6] Todd, D.K. (2007) Groundwater Hydrology. 2nd Edition, 3rd Reprint, John Wiley and Sons, Inc., India.

[7] State Water Resources Control Board (2016) Groundwater Information Sheet. Salinity, Division of Water Quality, GAMA Program, USA.

http://www.waterboards.ca.gov/gama/docs/coc_salinity.pdf

[8] United States Geological Survey (2016) Sources of Dissolved Solids in Brackish Groundwater. http://water.usgs.gov/ogw/gwrp/brackishgw/sources.html

[9] Boyd, C.E. (2000) Water Quality an Introduction. Kluwer Academic Publisher, USA, 330 p.

[10] Hem, J.D. (1985) Study and Interpretation of the Chemical Characteristics of Natural Water. 3rd Edition, U.S. Geological Survey Water-Supply Paper, Vol. 2254. Washington DC.

[11] Hem, J.D. (1991) Study and Interpretation of the Chemical Characteristics of Natural Water. Geological Survey Water-Supply Paper 1973, U.S. Government Printing Office, Washington DC, $363 \mathrm{p}$.

[12] Boyd, C.E. (1999) Water Quality: An Introduction. Kluwer Academic Publishers Group, The Netherlands.

[13] Detay, M. (1997) Water Wells-Implementation, Maintenance and Restoration. John Wiley 
and Sons, London, $379 \mathrm{p}$.

[14] Werkema, D.D. (2002) Geoelectrical Response of an Aged LNAPL. Plume: Implications for Monitoring Natural Attenuation. Unpublished PhD Dissertation, Western Michigan University, $136 \mathrm{p}$.

[15] Ledesma-Ruiz, R., Pastén-Zapata, E., Parra, R., Harter, T. and Mahlknecht, J. (2015) Investigation of the Geochemical Evolution of Groundwater under Agricultural Land: A Case Study in Northeastern Mexico. Journal of Hydrology, 521, 410-423. https://doi.org/10.1016/j.jhydrol.2014.12.026

[16] Al-Shidi, F.K.R. (2014) Study the Quality of Groundwater of Al-Zoroup Area in Mhdah State, the Sultanate of Oman. MSc Thesis, United Arab Emirates University, College of Science, $160 \mathrm{p}$. http://scholarworks.uaeu.ac.ae/cgi/viewcontent.cgi?article=1010\&context=all_theses

[17] Atekwanaa, E.A., Atekwanaa, E.A., Roweb, R.S., Werkema Jr., D.D. and Legalld, F.D. (2004) The Relationship of Total Dissolved Solids Measurements to Bulk Electrical Conductivity in an Aquifer Contaminated with Hydrocarbon. Journal of Applied Geophysics, 56, 281-294. https://doi.org/10.1016/S0926-9851(04)00057-6

[18] Advanced Purification Engineering Corp. (2016) Water Quality, Total Dissolved Solids in Water. http://www.freedrinkingwater.com/water-education2/72-tds-water.htm

[19] Safe Drinking Water Foundation (2016) TDS AND pH. http://www.safewater.org/PDFS/resourcesknowthefacts/TDS_AND\%20_pH.pdf

[20] Mackereth, F.J.H., Heron, J. and Talling, J.F. (1978) Water Analysis, Scientific Publication No. 36. Fresh Water Biological Association, 120 p.

[21] Dezuane, J. (1997) Handbook of Drinking Water Quality. 2nd Edition, John Wiley and Sons.

[22] Drever, J.I. (1997) The Geochemistry of Natural Water, Surface and Groundwater Environments. 3rd Edition, Prentice Hall, USA, $436 \mathrm{p}$.

[23] Wood, W.W. (1976) Guidelines for Collection and Field Analyses of Groundwater Samples for Selected Unstable Constituents. Techniques of Water-Resources Investigations of the United States.

[24] Meddis, R. (1975) Statistical Handbook for Non-Statisticians. McGraw-Hill Book Company, UK, $161 \mathrm{p}$.

Scientific Research Publishing

\section{Submit or recommend next manuscript to SCIRP and we will provide best service for you:}

Accepting pre-submission inquiries through Email, Facebook, LinkedIn, Twitter, etc. A wide selection of journals (inclusive of 9 subjects, more than 200 journals)

Providing 24-hour high-quality service

User-friendly online submission system

Fair and swift peer-review system

Efficient typesetting and proofreading procedure

Display of the result of downloads and visits, as well as the number of cited articles

Maximum dissemination of your research work

Submit your manuscript at: http://papersubmission.scirp.org/

Or contact eng@scirp.org 